Article

\title{
Monitoring and Managing Human Stressors to Coastal Cultural Heritage in Svalbard
}

\author{
Sanne Bech Holmgaard *, Alma Elizabeth Thuestad ${ }^{\circledR}$, Elin Rose Myrvoll and Stine Barlindhaug \\ Norwegian Institute for Cultural Heritage Research (NIKU), The Fram Center, Hjalmar Johansens gate, \\ 149007 Tromsø, Norway; alma.thuestad@niku.no (A.E.T.); elin.rose.myrvoll@samediggi.no (E.R.M.); \\ stine.barlindhaug@samediggi.no (S.B.) \\ * Correspondence: sanne.holmgaard@niku.no; Tel.: +47-4-0300339
}

Received: 23 November 2018; Accepted: 23 January 2019; Published: 28 January 2019

\begin{abstract}
Svalbard's cultural heritage sites are important remnants of an international history in the High North. Cultural heritage in the Arctic is being impacted by climate and environmental change as well as increased human activity. Tourism is a potential cause of transformation in cultural heritage sites, such as increased wear and tear, creation of paths and traces as people walk through cultural environments. Cultural heritage management is therefore an increasingly challenging endeavor as management authorities must take under consideration multiple impacts and threats to cultural heritage sites in a changing environment. Based on research conducted in Svalbard from 2014 to 2016 on methods for long-term systematic cultural heritage monitoring, this paper will discuss dilemmas for a sustainable use and management of vulnerable cultural heritage sites in the Arctic.
\end{abstract}

Keywords: cultural heritage; management; tourism; climate change; environmental stressors; the Arctic

\section{Introduction}

This paper contributes to an increased understanding of stressors to cultural heritage in a rapidly changing climate and with increased human impact. Cultural heritage sites can be vulnerable to several site transformation processes linked to climate change and environmental hazards as well as human activity (Risan et al. 2011; Sabbioni et al. 2010). Climate change impact on cultural heritage constitutes a growing field of scholarly interest, and the potential risks and effects of a warmer and more humid climate on built heritage have been widely recognized (e.g., Fatorić and Seekamp 2017; Hall 2015; Harvey and Perry 2015). Several kinds of geo-threats such as erosion, earthquakes, earth avalanches, and flooding have also been demonstrated to pose threats to cultural heritage sites (Flyen 2009; Reeder-Myers 2015). To what extent and in what ways cultural heritage sites are impacted by environmental stressors depend on the vulnerability of the site and on the extent of stressors. Tourism is a potential cause of transformation in cultural heritage sites, such as increased wear and tear, creation of paths and traces as people walk through cultural environments, physically disturbing structures, moving or removing loose objects, adding objects, etc. (Hall 2015; Roura 2011). The impact of human traffic on cultural heritage sites depends on the type, time, activity, and intensity of the visitors as well as the condition of the site. Therefore, in-depth knowledge of sites and activities as well as monitoring data on site transformations is needed to enable cultural heritage management to take threats, vulnerabilities, and impact into proper consideration.

In Arctic Polar areas, climatic changes are happening rapidly and changing environmental conditions are impacting cultural heritage sites (Hollesen et al. 2017; Øseth 2010). At the same time, an expanding tourism industry in Polar regions brings large amounts of people to areas previously not visited by tourists. This increased human traffic can potentially cause further deterioration to 
vulnerable cultural heritage sites (Hagen et al. 2012). Cultural heritage management in Arctic areas is therefore an increasingly challenging endeavor as management authorities must take into consideration multiple impacts and threats to cultural heritage sites in a rapidly changing environment.

In Svalbard, cultural heritage sites and environments are well documented and the general knowledge of threats to cultural heritage is already substantial. However, to monitor changes in sites and environments over time, more detailed data on how sites are changing, and the extent of stressors, are needed.

This paper is based on results from multidisciplinary research carried out in Svalbard from 2014 to 2016. The research included fieldwork on different types of cultural heritage sites in Svalbard. In this paper, we are building upon our results from remote sensing analysis, archeological surveys, and analysis of the political and societal aspects related to human impact and tourism-development in Svalbard. We will synthesize results on stressors to cultural heritage and their impact and discuss stressors in a wider context of the societal developments and tourism in Svalbard. Taking multiple stressors to cultural heritage into consideration, we will discuss challenges for a sustainable use and management of vulnerable - and valuable-cultural heritage sites in the Arctic, taking the political and economic aspects of Arctic tourism and development into consideration. The aim of this approach is to contribute to a comprehensive analysis of the stressors to cultural heritage in Polar regions, impacted by rapid climatic as well as societal changes.

\section{Cultural Heritage in Svalbard-History and Management}

Located in the Arctic Sea, stretching from $74^{\circ}$ to $81^{\circ}$ north, the Archipelago of Svalbard is one of the world's most northerly and remotely inhabited settlements. Following its first recorded discovery by Dutch explorer Willem Barentsz in 1596, Svalbard became a destination for sea-based hunts, expeditions and the search for exploitable natural resources. Many nations participated in these activities, making Svalbard an international arena for whaling, hunting, scientific explorations, and mining. The earliest known human activities include extensive whaling activity by the Dutch, Basque, English, and Danish-Norwegians in the decades following Svalbard's discovery (Arlov 2003). In the 18th and early 19th century, Russian Pomors took control of the Archipelago and carried out hunting and trapping for profitable products such as winter furs of Arctic fox and polar bear as well as walruses, seals, and white whales. Russian hunters and trappers were the first to conduct all-year activity and overwinter in Svalbard's extreme conditions. From the end of the 18th century, Norwegian trappers also overwintered in Svalbard. In the mid-19th century, there was a breakthrough in scientific explorations and research in Svalbard, and the Archipelago became an important stopover for Arctic explorers of different nationalities. The motivations and rationales of scientific expeditions have alternated over the years, but research has often been closely connected with both the exploitation of natural resources and the political or economic interests of nations, companies, and individuals (Arlov 2003; Sandodden 2013; Viken 2011).

Until the end of the nineteenth century, Svalbard's economic importance stemmed from hunting commodities such as blubber, ivory, fox pelts, polar bear furs, seal skins, and other products from whaling, hunting, and trapping activities. Towards the end of the 19th century, minerals were discovered in Svalbard, such as copper, iron, marble, and zinc. No resources, however, were to become as lucrative and productive as coal. Svalbard's first permanent settlement came with the 1906 founding of Longyearbyen by the American-owned Arctic Coal Company, which was sold in 1916 to what would become Store Norske coal company (Grydehøj 2010). Up until the First World War, many mining projects were initialized, and land occupied in the Archipelago. Svalbard was at the time regarded as "terra nullius", a no-man's land, leading to at times chaotic conditions and territorial disputes between different interests (Arlov 2003). In 1920, an international treaty was signed, granting Norway sovereignty over Svalbard and all signatory countries the right to carry out economic activities (Svalbard Treaty 1920). 
The extensive exploration and exploitation of natural resources has left a multitude of traces throughout the Archipelago, constituting a highly international and unique cultural heritage (Barr 2004; Sandodden et al. 2013). Cultural heritage sites and objects in Svalbard are well documented and registered. According to the Norwegian National Heritage Database (Askeladden), there are 2140 cultural heritage sites containing 3513 heritage objects in the Svalbard Archipelago (Directorate for Cultural Heritage 2017; see Figure 1). Cultural heritage sites in Svalbard are mainly tied to human activity in coastal areas. Throughout the human history of Svalbard, similar criteria have been decisive when choosing where to establish activities and settlements, including closeness to resources, easy access and landings, protection against stormy weather and easy access to fresh water and driftwood. This means that cultural remains from different periods and activities are often gathered at mixed heritage site locations along the coast (Johansen et al. 2011). Cultural heritage sites thus cover different activities and historical eras, from whaling activities (ca. 1600-1750), Russian and Norwegian overwintering hunting and trapping (ca. 1700-1850 and ca. 1800-present, respectively), research and expeditions (ca. 1800-present), extractive industries (ca. 1900-present) and World War II (1941-1945).

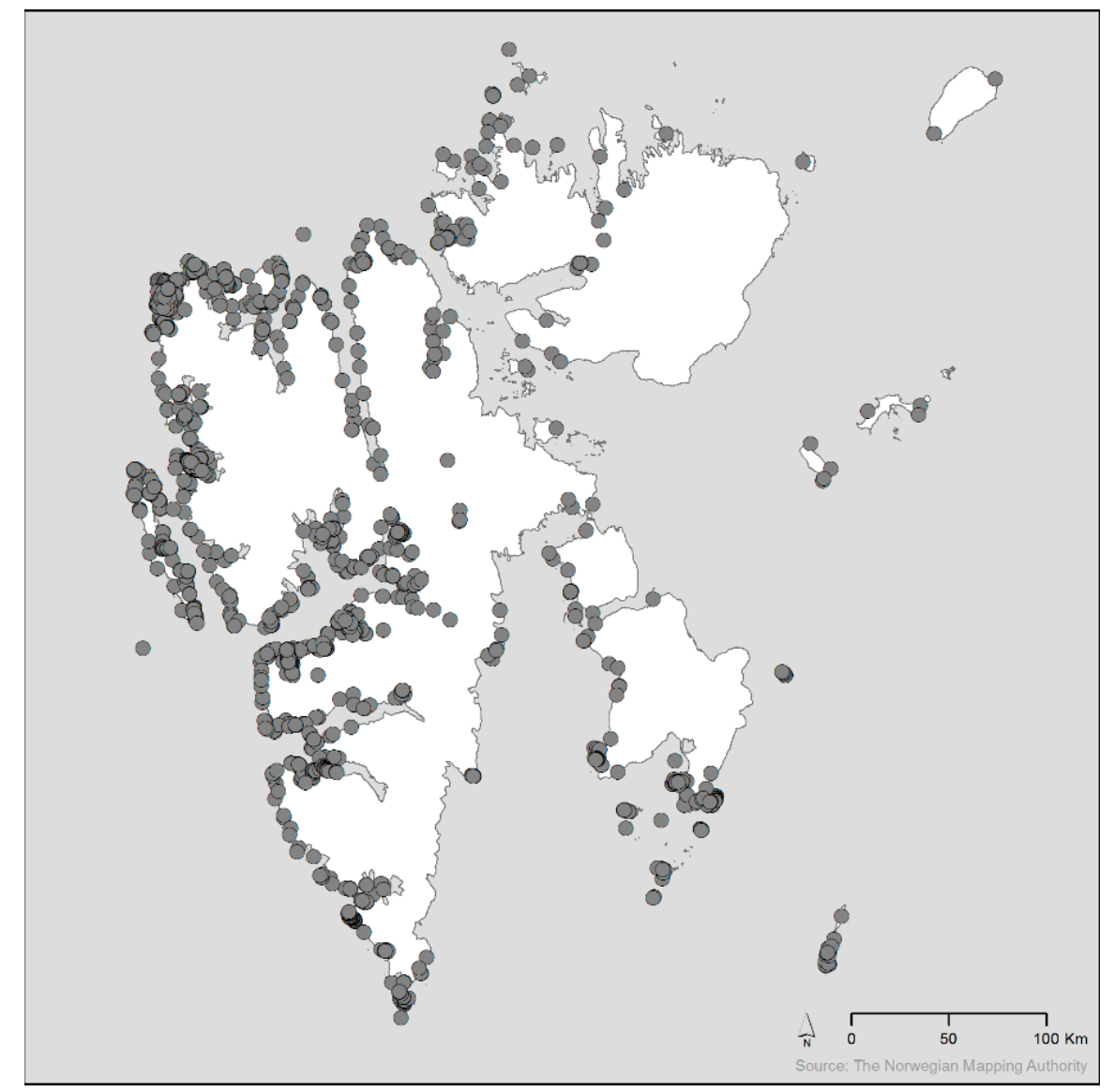

Figure 1. Maps of cultural heritage sites in Svalbard (map by Alma Thuestad, NIKU).

The Svalbard Treaty has implications for management, as it gives Norway the responsibility to protect the natural environment and cultural heritage. The Svalbard Environmental Protection Act, passed in 2001, governs a range of important issues for the Archipelago, including protected areas, flora and fauna, land-use planning areas, activities with environmental impact-and cultural heritage. The overall purpose of this Act is to preserve a "virtually untouched environment in Svalbard with respect to continuous areas of wilderness, landscape, flora, fauna, and cultural heritage" (Svalbard Environmental Protection Act 2001, sct. 1). Natural and cultural heritage are considered jointly as part of the environment and the Act explicitly states that the cultural heritage of Svalbard shall be protected as an element of a coherent system of environmental management (Svalbard Environmental 
Protection Act 2001). In Svalbard, all traces of human activity dating from 1945 or earlier are legally considered protected elements of cultural heritage. This protection applies to stationary artifacts such as buildings and ruins, as well as unattached artifacts, such as stove rings, oil barrows, trapping devises, tools, ammunition, and many others. This means that in Svalbard, many buildings and objects are protected, which would not have been so on the Norwegian mainland. This also means that automatically protected heritage is relatively new and the line between what is heritage and what is for example industrial waste might not easily be detected without prior knowledge of the history of the sites. The Governor of Svalbard has in place a Plan for the management of cultural heritage in Svalbard from 2013 to 2023 which includes a plan of action for 100 prioritized sites. These sites have been selected to be representative of cultural heritage sites dated before as well as after 1946 . The degree of care and maintenance of the priority items ranges from monitoring to comprehensive restoration and maintenance (Sandodden et al. 2013).

\section{Environmental and Human Stressors to Cultural Heritage in the Arctic}

In the Arctic, the air temperature is increasing two to four times faster than the global average and the earliest and most substantial changes to ecosystems are expected in these areas (Hansen et al. 2014; Øseth 2010). A higher mean temperature can affect cultural environments and landscapes as it might alter conservation conditions for cultural heritage and create more favorable conditions for bio-deterioration with rotting and decaying archaeological features. In the Arctic, such processes have been demonstrated in cultural heritage structures as well effects of thawing permafrost (Flyen and Mattsson 2013; Hollesen et al. 2017). In addition to climatic change, natural hazards and harsh environmental conditions are known threats to cultural heritage in Svalbard such as coastal erosion, wind wear and tear, sand drift, and flooding (e.g., Barr 2011; Hagen et al. 2012; Sandodden et al. 2013; Thuestad et al. 2015a, 2015b).

In recent years, human impact on cultural heritage has been a topic of increasing relevance in the Arctic due to an expanding tourism industry. The number of tourists arriving in Svalbard has increased significantly over the past decades (Statistics Norway 2016). Most tourists who travel beyond the immediate vicinity of the main settlement of Longyearbyen travel by cruise ships (Hagen et al. 2012). Cruise-ship tourism in the Arctic is characterized by growth, diversification, and geographic expansion (Roura 2010; Stewart et al. 2005). Although the number of passengers on large overseas cruise ships has also increased significantly, cruise-ship tourism in Svalbard is largely characterized by "expedition cruising", with vessels comparatively small and thus able to land people ashore despite a lack of infrastructure (Roura 2010, p. 185; Statistics Norway 2016). There has been a significant increase in both the number of people ashore and number of disembarkation sites since the mid-1990s. With a rise from 39,109 passenger disembarkations from cruise ships on 76 landing sites in 1997 to 131,286 disembarkations on 195 landing sites in 2014, there has thus been a large increase in human traffic (Thuestad et al. 2015a). This is the case for the main settlement of Longyearbyen which has seen a significant increase in overnight stays (Statistics Norway 2016), but the increase in disembarkation sites also shows that more people are scattered around the coastal areas and in the natural environment. This is likely to affect areas not previously impacted by human traffic.

In addition to the natural environment, the landscape, and iconic wildlife, tourists are drawn to the history of Svalbard, and cultural heritage sites are main attractions at many visitor sites (Roura 2010). Cultural heritage sites are attractive destinations for cruise-ship landings, as they are sites of material remains and history with both something to show and stories to tell (Roura 2010, p. 187). Many heritage sites are highly visible in the landscape and testify to the history of human explorations, people coping in tough and extreme conditions in a remote wilderness and thus include the myths, legacy, and relics of the age of exploration, the archaeological remains of early whaling, cabins, graves, and tools of hunting and trapping activities and the materiality of the mining industry (Hagen et al. 2012; Norum 2016). Tourism is known to be a potential contributor to processes of transformation and decay in cultural heritage, with visitor impact linked to people walking through cultural environments, physically 
disturbing structures, moving or removing loose objects, adding objects, and so on, in addition to increased wear and tear (Fyall and Garrod 1998; Hall 2015; Roura 2011). Over time, such activities can damage or even destroy cultural heritage features, and consequently contribute to degrading or even destroying valuable cultural heritage sites. This means that the increased human traffic from tourism is a potential impact and driver for site transformation for cultural heritage sites in Svalbard.

A comprehensive environmental monitoring program for Svalbard and Jan Mayen, MOSJ, was established in the late 1990s. Existing indicators for MOSJ focus on ecological factors and human impact such as the population sizes of Arctic mammals, fish and birds, ice and snow conditions, sea levels, climate gases, temperatures, pollutants in different species, hunting bags for huntable species, and a range of other relevant ecological indicators for which data is collected. At the same time, the number of snowmobiles, cruise-ship tourists, and disembarkation sites are monitored to give an indication on the human activities, and thus anthropogenic stressors, outside of the main settlements. Cultural heritage sites are also a topic of monitoring in MOSJ, and since its initiation, work has been underway to develop indicators to integrate cultural heritage in this monitoring system (MOSJ 2016). However, developing indicators for cultural heritage monitoring has been difficult and taken time. One reason for this delay has been that methods and indicators were not readily available and had to be developed (Barlindhaug et al. 2017). A focal point for cultural heritage monitoring is detecting and assessing the changing state of cultural heritage assets. Through monitoring cultural heritage sites, relevant knowledge for decision-making and regulations for use of cultural heritage can be generated. This requires knowledge of the current state and vulnerabilities as well as an understanding of natural and anthropogenic site transformation processes. A need for detailed monitoring data on cultural heritage sites has been articulated by national as well as local authorities and management agencies in Svalbard (e.g., Bjerck 1999; Riksrevisjonen 2007). Results from this study have been used to develop indicators for the monitoring of cultural heritage sites in Svalbard (Barlindhaug et al. 2017).

\section{Case Studies and Methods}

During 2014, we surveyed seven cultural heritage sites located in northwest Svalbard to assess the state of structures and objects to provide a basis for developing protocols for systematic monitoring. This study was done as part of a research project on natural and human impact on cultural heritage sites and environments in Polar regions (CULPOL). The selected sites are affected by a range of the known environmental hazards accounted for above, such as coastal erosion, wind wear and tear and more damp conditions due to climate change. Sites include a whaling station from the early 1600s, three gravesites (Liknesset, Gjøanes, Gravnesset), an industrial site with remnants of marble mining and related activities in the early 1900s (London), a mixed site including a whaling station, graves and trapping station (Sallyhamna) and a mixed site with a whaling station, including blubber ovens and gravesites, remnants of Swedish balloonist S.A. Andrée's Arctic balloon expedition (1896-1897) as well as remnants from Walter Wellman's airship expeditions to the North Pole (1906-1909) (Virgohamna, see Figure 2). All sites are, with one exception chosen for control purposes, popular tourist destinations.

We utilized high-resolution aerial photographs and imagery acquired using an Unmanned Aerial System (UAS) in combination with ground-based surveys to assess the state of sites and potential stressors and drivers of change (see Figure 3 for an example of the UAS images of Smeerenburg). The latter included comprehensive documentation of the state of archaeological features and vegetation cover in and around sites. We have found vegetation on and around features to be a useful indicator for monitoring the state, vulnerabilities, and transformations of cultural heritage sites. The vegetation cover plays a key role regarding degradation and erosion of cultural monuments as vegetation on many sites provides a form of "protective cover". Worn or damaged vegetation exposes heritage features to erosion and makes them more vulnerable to impact from wear and tear, both climatic and human. Monitoring vegetation will thereby provide information on changing state and vulnerabilities of cultural heritage sites (Thuestad et al. 2015b). 


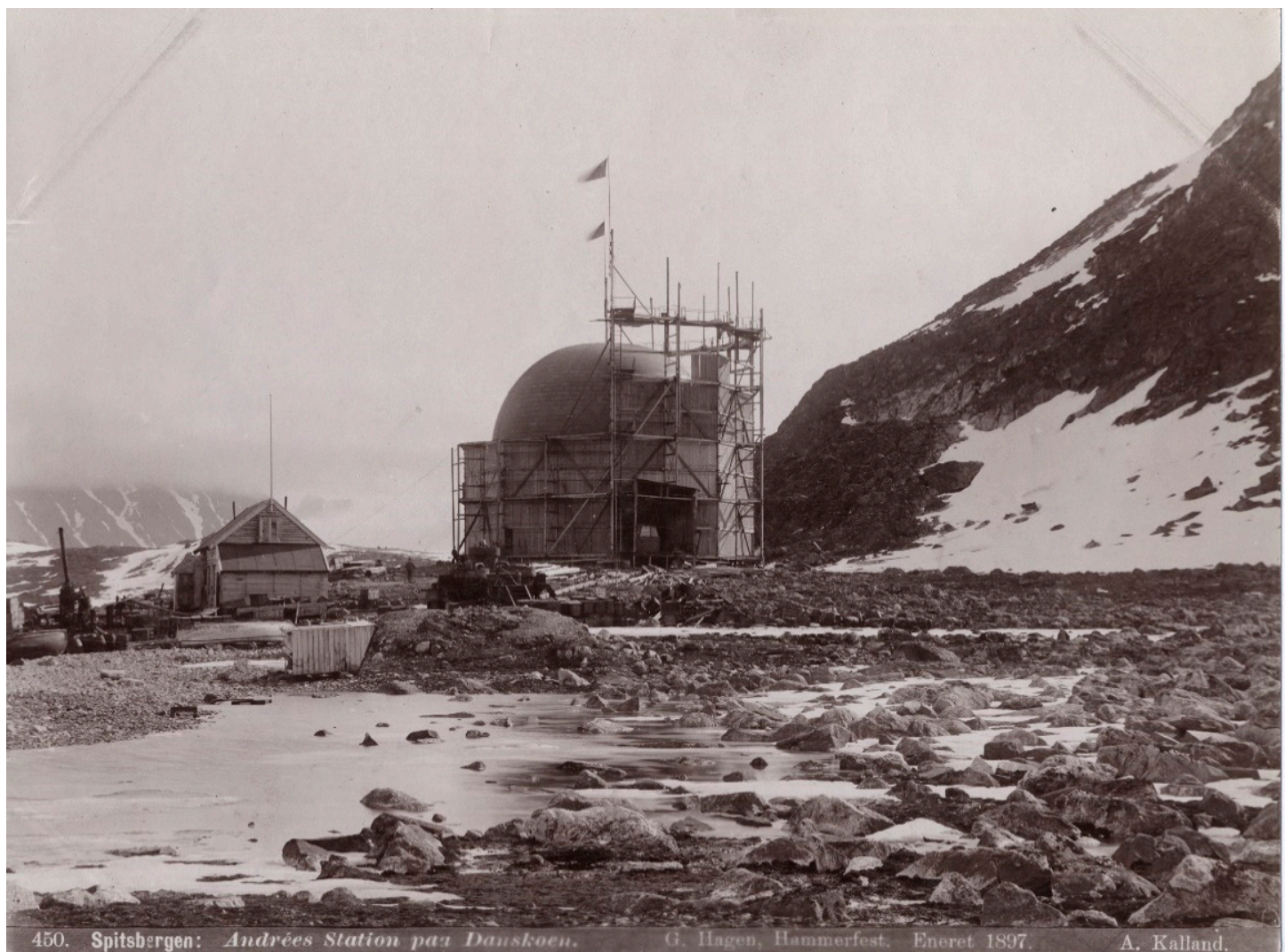

Figure 2. Virgohamna was a base for several famous expeditions attempting to reach the North Pole in the late 1800s and early 1900s. Picture taken in 1897 by Ludvig Blunck. (C) Norwegian Polar Institute.

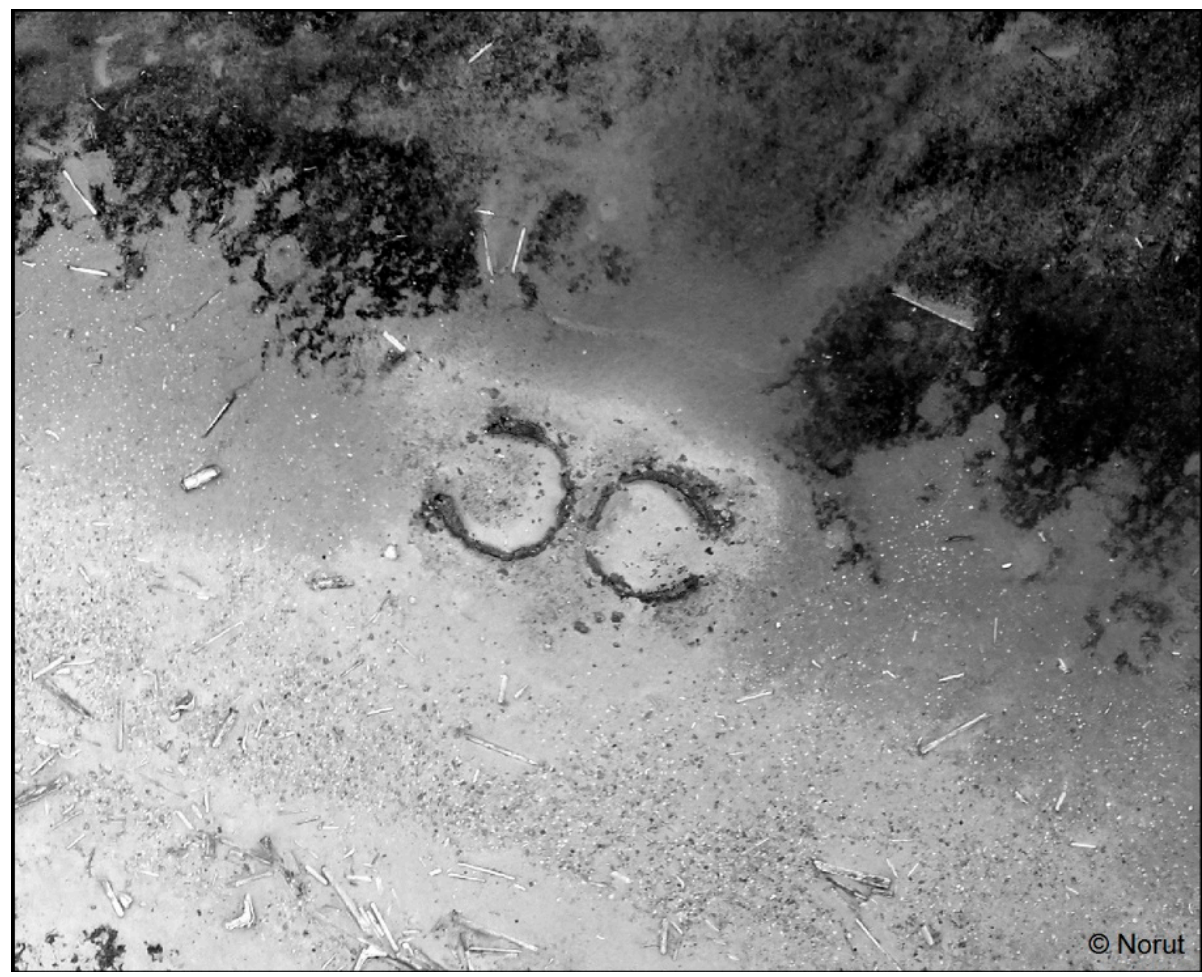

Figure 3. Smeerenburg was the main base for Dutch whaling in the 1600s. The most visible remains today are the tryworks for rendering oil, the so-called blubber ovens. Image of blubber oven remains acquired by UAS in 2014. ( $)$ NORUT. 
The remote sensing data were subjected to visual analyses and classification as well as change detection procedures. Visual data from our fieldwork was referenced with high-resolution satellite images from 1990 and 2009. This gave us the opportunity to detect changes in vegetation cover over time (for a comprehensive account of remote sensing data and methods used, see Thuestad et al. 2015a, 2015b). Using high-resolution image data, we were able to detect even subtle changes in vegetation as well as deterioration of cultural heritage.

From our case studies, we see that impact on cultural heritage could be detected, especially on and around cultural heritage features. To verify these results, ground-based archaeological registrations were conducted, with photographic and written documentation. This served to ground truth and supplement analysis of remote sensing data and to contribute to a grounded knowledge of the cultural heritage sites, conditions, and vulnerabilities to inform the development of indicators for monitoring. Like the remote sensing analysis, ground-based surveys showed signs of worn vegetation in cultural heritage environments, and traces of walking, trampling, and other activities such as moved objects and removed soil layers (Thuestad et al. 2015b). Viewed together, the results from the image analyses and the ground-based surveys clearly indicate a gradual and ongoing deterioration of the vegetation cover in the surveyed sites, especially in areas surrounding the popular and much-visited cultural heritage features.

Determining the exact distribution of environmental and human stressors respectively is difficult based on existing data. We did find that the deterioration of cultural heritage sites and vegetation cover coincided with a significant increase in cruise-ship landings at the surveyed sites (Thuestad et al. 2015b). Wear and tear caused by human traffic, such as paths from the shore to heritage sites and around sites, could be observed and linked to increased numbers of visitors at sites. Damages to vegetation can increase erosion and natural and human stressors are thereby potentially mutually reinforcing (Barlindhaug et al. 2017; Thuestad et al. 2015b). Environmental- and anthropogenic-induced site transformation processes are likely to be mutually reinforcing, with the combined impact contributing to the ongoing deterioration of cultural heritage. Indicators for monitoring will therefore need to capture human as well as environmental and climatic impacts. This includes indicators for coastal erosion, abrasion from human traffic, meltwater, vegetation, items removed or covered, etc. (for a complete list of specific indicators, see Barlindhaug et al. 2017)

Environmental stressors such as coastal erosion, climate change, and bio-deterioration are largely beyond the control of cultural heritage management. Human traffic can, however, more easily be managed as site access can be limited or sites facilitated to direct peoples' movements through planned trails or fenced areas. Today, most sites do not have restricted access and the control of visitors are larely dependant upon the instructions and supervision by tour guides (see Figure 4 for an example of tourists visiting a cultural heritage site) Our results indicate that remote sensing can be a suitable way of monitoring the impact of environmental as well as human stressors on cultural heritage. Monitoring data using indicators for human as well as environmental impact will give management authorities the opportunity to assess the state and impact on cultural heritage sites at an early state, enabling protection measures to be taken before more significant damage occurs. As will be discussed in the following section, such measures will be taken in a complex environment of political, social, and economic interests, including the development and expansion of Polar tourism In Svalbard. 


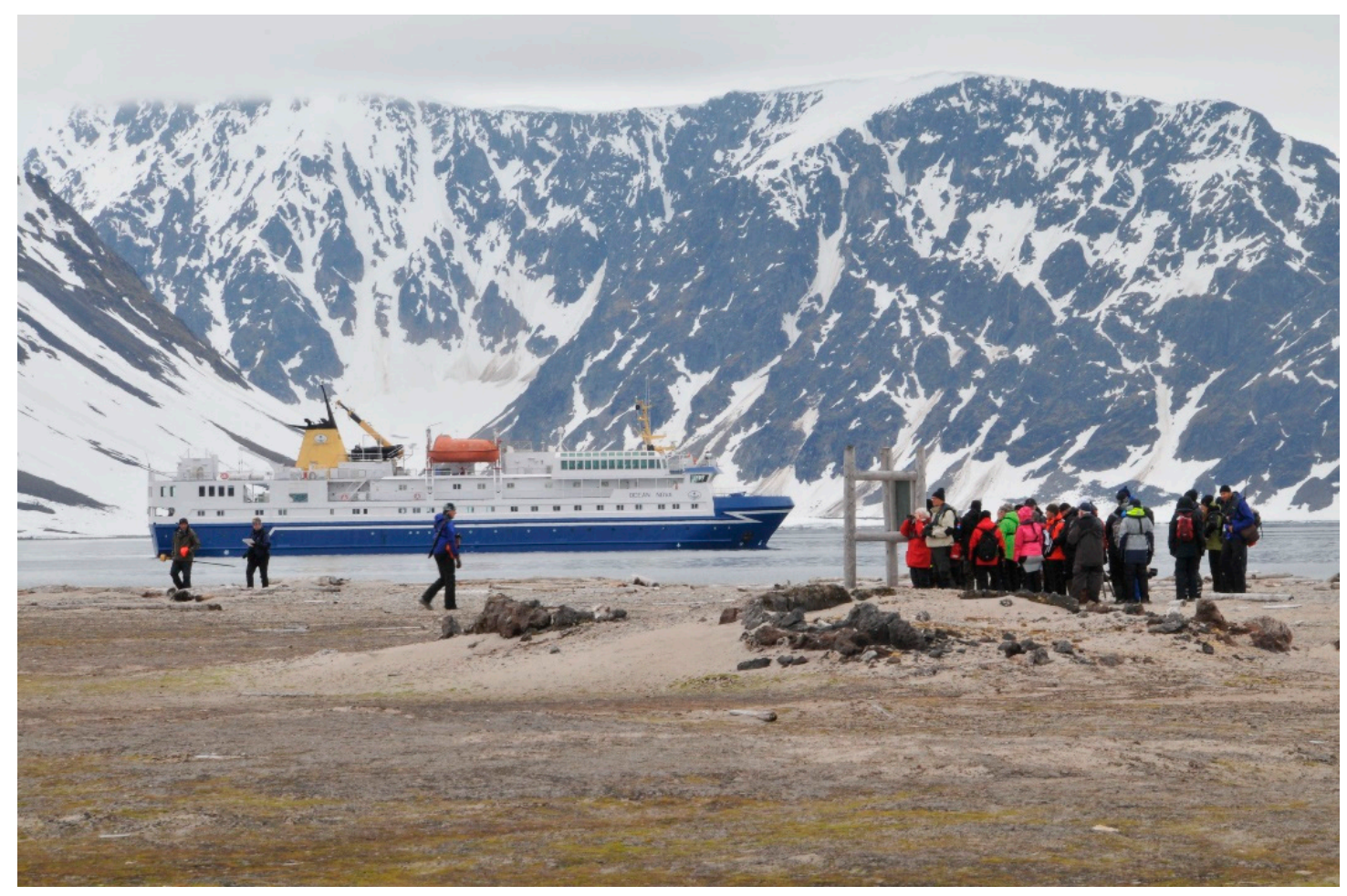

Figure 4. Cruise-ship tourists visiting Smeerenburg. ㅇ Elin Rose Myrvoll 2014.

\section{The Development and Significance of Tourism in Svalbard}

Arctic tourism has become a hot topic, not only due to the growing numbers of tourists, but also due to an increased focus on the Arctic caused by climate change and heightened attention to the economic and geopolitical importance of Arctic areas (Müller 2015). In many Arctic peripheral communities, small populations and long-time economic dependency on extractive industries have created a situation where few alternatives for income-generating activities are available. In Svalbard, tourism is certainly one such opportunity, together with scientific research and education (Müller 2015, pp. 147-48; Viken 2011). In the 1990s, the Norwegian government initialized a focus on the development of tourism in Svalbard as an alternative economy to the declining mining industry. The purpose of this was not only to fulfil economic goals, but also to maintain a viable Norwegian settlement and safeguard Norwegian interests in the Arctic (Ministry of Justice and Public Security 2016; Ministry of Justice and the Police 2008; Norum 2016). Today, tourism is more important in employment and revenue than the mining industry (Statistics Norway 2016, pp. 14-15). Several Norwegian and Russian companies are focusing on developing tourism, including the largest coal companies of both nations, Store Norske and Arktikugol State Trust, who have included tour operations in their business strategies (Veselov 2015; Engås 2016). Both companies still have active coalmines, in Longyearbyen and Barentsburg, respectively. However, in 2017 the Norwegian government decided to discontinue subsidy to coal mining, and now the only operating Norwegian mine is a smaller deposit kept in operation to secure supplies for the locally run power-plant. As it has been the case of mining and research activities in Svalbard (Norum 2016), tourism now plays an important role in maintaining Norway's strong position in the Arctic (Timothy 2010, p. 295; Viken 2011, p. 344).

Public images of Polar regions tend to evoke a somewhat stereotypical ideal of a pristine and vulnerable wilderness untouched by nature-disturbing humans (Steinberg et al. 2015, p. 158). Such images are also evident in Polar tourism, with an emphasis on the unspoiled magnificent natural surroundings and a last chance to see a rapidly disappearing world and its natural inhabitants, most notably the polar bear. Traveling in the footsteps of explorers and adventurers has been an important part of the attraction of Polar tourism since its early stages (Berger 2010, p. 52; Müller 2015; Nuttal 2010). 
Making explicit connections between great historical Arctic expeditions and today's tourism is clearly also induced by tourism operators in Svalbard, creating a direct link between great polar explorers and the modern-day traveler. Under the heading "Plant Your Flag!" the tour operator the Norwegian Coastal Steamer promotes their fleet of explorer cruise ships through references to historic Polar expeditions and promises to make you "connect with your inner explorer" in remote destinations, including Svalbard (Hurtigruten 2015). Abandoned mining towns are other main attractions of Svalbard tours, actively branded as abandoned, eerie places in which time has stood still. Svalbard itself is described as a risky place where danger is lurking around every corner which may not portray a true image of organized cruise-boat tourism, but rather serve to enhance the tourists' experience (Hurtigruten 2016; Nuttal 2010, p. 206).

\section{Cultural Heritage in Arctic Areas: Politics, Development, and Vulnerability}

In the Svalbard Environmental Protection Act, a pronounced aim is to maintain a pristine and untouched natural environment as well as cultural heritage (Svalbard Environmental Protection Act 2001, sct. 1). As argued in this paper, cruise-ship tourism with increasing landing sites and people ashore can put significant pressures on vulnerable cultural heritage in Svalbard's coastal areas, which, in combination with environmental stressors, causes a deterioration of the sites monitored in our research. At the same time, the growth of the tourism industry is desired and supported by government policy. With decreasing coal mining activity and thus a lesser degree of employment and economic significance of this industry, tourism is intended to play, and indeed already plays, an important role in the maintenance of a viable Svalbard community and thereby also plays an important role in the legitimacy of Norwegian influence and interests in Svalbard and in the Arctic (Timothy 2010, p. 295; Viken 2011). Management objectives and political strategies thus to some extent seem to be expressing conflicting aims, with the former emphasizing high ambitions to preserve "untouched" cultural heritage and natural environment and thus protect it from human impact, whereas the latter advocates an active exploitation of cultural heritage in tourism activities. The very idea of leaving cultural heritage untouched might seem something of an oxymoron that contains a conflict between human activity and pristine wilderness. As noted by Sander et al., "The inclusion of cultural heritage protection in Norwegian environmental management helps to bring out an interesting conflict of views on the nature of the landscape in Svalbard. Is it the undisturbed wilderness, or a cultural landscape marked by centuries of human use?" (Sander et al. 2006, p. 18). We argue that similar contradictions of aims exist in management of cultural heritage as parts of a pristine and untouched environment and, at the same time, the active exploitation of heritage sites in tourism. Cultural heritage management in Svalbard is thus an increasingly challenging endeavor as it must take into consideration the number of threats and stressors to cultural heritage and protect heritage values, while at the same time enabling an active exploitation of cultural heritage in the rapidly growing and expanding tourism industry. Monitoring cultural heritage sites can help a sustainable management of coastal cultural heritage sites in Svalbard, as well as in other areas impacted by environmental as well as human stressors. Such monitoring will, over time, give management agencies useful data on site transformations and the main stressors to different sites. Monitoring data using indicators for human as well as environmental impact will give management authorities the opportunity to assess the state and impact on cultural heritage sites at an early state, enabling protection measures to be taken before more significant damage occurs.

Archaeological remains of early whaling have been given the most restrictive protection of cultural heritage in Svalbard. However, restrictions such as fencing cultural heritage sites can have a negative impact on people's experience of cultural heritage (Sandodden et al. 2013, pp. 64-66). Consumer experiences are regarded as the locus of value creation in the tourism industry, with a focus in tourism research on understanding and facilitating meaningful consumer experiences (Lindberg et al. 2014). In the case of Svalbard, one important question remains to be explored, namely how tourists in Svalbard will respond to explicitly organized and facilitated cultural heritage sites. The social 
impact, i.e., human perceptions of impact on sites and structures, might not be as easy to quantify as environmental and human impact, but is nonetheless important in the sustainable use and management of cultural heritage values (Hagen et al. 2012). Insight into what constitutes a meaningful tourist experience is needed to determine in what way management of cultural heritage and facilitation of cultural heritage sites might support or counteract political aims of promoting and developing tourism. Monitoring cultural heritage sites will help determine how such development might take place without significantly damaging vulnerable cultural heritage sites and structures.

Our main concern in this paper has been with aspects related to monitoring and management of cultural heritage sites, whereas conservation of tangible cultural heritage has not been addressed in detail. However, results from monitoring can be useful in mitigation efforts as well as conservation of cultural heritage sites. Monitoring cultural heritage sites is an important tool for generating relevant data and knowledge, which can form the basis of informed decision-making in managing cultural heritage sites. Cultural heritage sites are vulnerable to human as well as environmental stressors and different stressors are potentially mutually reinforcing. A monitoring program must therefore take into account several different indicators, covering different scales of the actual heritage sites as well as the area around.

Our research has shown that monitoring damages to vegetation will give insight into the impact of increased tourism and traffic on cultural environments and thereby establish the level for acceptable impact and sustainable tourism. To do so, remote sensing methods are cost-effective and non-intrusive ways of gathering relevant data for monitoring cultural heritage sites. The importance of monitoring site transformations and the state of cultural heritage sites is likely to increase in the future, due to climate change and increased human traffic.

Author Contributions: All authors made valuable contributions to the manuscript. S.B.H. is the main author and conceptualized the idea of the manuscript and was responsible for its completion and revision. S.B. was the project leader for the CULPOL research project in which this research was carried out and has contributed text and revisions to the manuscript. A.E.T. carried out data analysis and has contributed to the writing of this paper, especially on the methods and data analysis. E.R.M., A.E.T. and S.B. were actively involved in data collection. All authors have been involved in funding acquisition.

Funding: This research was funded by The Norwegian Research Council, Grant number 226413/E10 and by the Fram Center, Fjord and Coast Flagship.

Conflicts of Interest: The authors declare no conflict of interest.

\section{References}

Arlov, Thor B. 2003. Svalbards Historie. [The history of Svalbard]. Trondheim: Tapir Akademisk Forlag.

Barlindhaug, Stine, Alma Elizabeth Thuestad, and Elin Rose Myrvoll. 2017. Kulturminneovervåking på Svalbard. Metodeutvikling for «MOSJ-Miljøovervåking Svalbard og Jan Mayen». NIKU Rapport 86. Available online: https:/ / www.niku.no/wp-content/uploads/2017/09/NIKURapport86.pdf (accessed on 5 January 2019).

Barr, Susan. 2004. Polar Monuments and Sites: An Introduction. In Cultural Heritage in the Arctic and Antarctic Regions. Edited by Susan Barr and Paul Chaplin. Compiled and Edited for the International Polar Heritage Committee of the International Council on Monuments and Sites. Oslo: ICOMOS IPHC, pp. 18-23.

Barr, Susan. 2011. Arctic and Antarctic-Different, but similar: Challenges of heritage conservation in the High Artic. In Polar Settlements-Location, Tecniques and Conservation. Edited by Susan Barr and Paul Chaplin. Compiled and Edited for the International Polar Heritage Committee of the International Council on Monuments and Sites. Oslo: ICOMOS IPHC, pp. 14-23.

Berger, Arthur Asa. 2010. Selling the Adventure of a Lifetime: An Ethnographic Report on Cruising in the Antarctic. In Cruise Tourism in Polar Regions: Promoting Environmental and Social Sustainability. Edited by Michael Luck, Patrick T. Maher and Emma J. Stewart. London: Earthscan, pp. 43-54.

Bjerck, Hein B. 1999. Overvåking av Kulturmiljø på Svalbard [Monitoring Historic Sites at Svalbard. Aims, Methodology and Monitoring]. Sysselmannens Rapportserie No. 3. Longyearbyen: The Govenor of Svalbard. 
Directorate for Cultural Heritage. 2017. Norwegian National Heritage Database. Available online: https:// askeladden.ra.no/Askeladden/Pages/LoginPage.aspx?ReturnUrl=\%2faskeladden (accessed on 26 January 2017).

Engås, Christopher. 2016. Store Norske blir reiselivsaktør. Svalbardposten, June 30. Available online: http: / / svalbardposten.no/nyheter/store-norske-blir-reiselivsaktor/19.7336(accessed on 20 January 2017).

Fatorić, Sandre, and Erin Seekamp. 2017. Securing the Future of Cultural Heritage by Identifying Barriers to and Strategizing Solutions for Preservation under Changing Climate Conditions. Sustainability 9: 2143. [CrossRef]

Flyen, Anne-Cathrine, and Johan Mattsson. 2013. Gruveminner I Longyearbyen og Hiorthamn. Fredete taubanebukker: Tilstand og bevaring. NIKU Rapport 68. Oslo: Norsk institutt for kulturminneforskning. (In Norwegian)

Flyen, Anne-Cathrine. 2009. Coastal erosion-A threat to the cultural heritage of Svalbard? In Polar Research in Tromsø 2009. Edited by Janet Holmén. Tromsø: University of Tromsø, pp. 13-14.

Fyall, Alan, and Brian Garrod. 1998. Heritage tourism: At what price? Manging Leisure 3: 213-28. [CrossRef]

Grydehøj, Adam. 2010. Uninherited heritage: tradition and heritage production in Shetland, Åland and Svalbard. International Journal of Heritage Studies 16: 77-89. [CrossRef]

Hagen, Dagmar, OddI Vistad, Nina E. Eide, Anne C. Flyen, and Kirstin Fangel. 2012. Managing visitor sites on Svalbard: From a precautionary approach towards knowledge-based management. Polar Research 31: 18432. [CrossRef]

Hall, C. Michael. 2015. Heritage, heritage tourism and climate change. Journal of Heritage Tourism 11: 1-9. [CrossRef]

Hansen, Brage B., Ketil Isaksen, Rasmus E. Benestad, Jack Kohler, Åshild Ø. Pedersen, Leif E. Loe, Stephen J. Coulson, Jan Otto Larsen, and Øystein Varpe. 2014. Warmer and wetter winters: Characteristics and implications of an extreme weather event in the High Arctic. Environmental Research Letters 9: 114021. [CrossRef]

Harvey, David, and Jim Perry, eds. 2015. The Future of Heritage as Climate Changes: Loss Adaptation and Creativity. Abingdon: Routledge.

Hollesen, Jørgen, Henning Matthiesen, and Bo Elberling. 2017. The Impact of Climate Change on an Archeological Site in the Arctic. Archaeometry 59: 1175-89. [CrossRef]

Hurtigruten. 2015. Connect with Your Inner Explorer. Available online: https:/ www.youtube.com/watch?v= K3MkgHKP8Hg (accessed on 31 January 2017).

Hurtigruten. 2016. Plant Your Flag. Available online: www.plantflags.com (accessed on 31 January 2017).

Johansen, Bjørn Fossli, Kristen Prestvold, and Øystein Overrein. 2011. Cruise Handbook for Svalbard. Tromsø: Norwegian Polar Institute.

Lindberg, Frank, Ann Heidi Hansen, and Dorthe Eide. 2014. A Multirelational Approach for Understanding Consumer Experiences Within Tourism. Journal of Hospitality Marketing and Management 23: 487-512. [CrossRef]

Ministry of Justice and Public Security. 2016. Svalbard. Norwegian White Paper No. 32. Available online: https: / / www.regjeringen.no/no/dokumenter/meld.-st.-32-20152016/id2499962/sec1 (accessed on 20 January 2017).

Ministry of Justice and the Police. 2008. Svalbard. Norwegian White Paper No. 22. Available online: https:/ /www. regjeringen.no/contentassets/e70b04df32ad45f483f2619939c5636d/no/pdfs/stm200820090022000dddpdfs.pdf (accessed on 20 January 2017).

MOSJ. 2016. Cruise Tourism. Environmental Monitoring of Svalbard and Jan Mayen. Available online: http: / / www.mosj.no/en/influence/traffic/cruise-tourism.html (accessed on 15 January 2017).

Müller, Dieter K. 2015. Issues in Arctic Tourism. In The New Arctic. Edited by Birgitta Evengård, Joan Nymand Larsen and Øyvind Paasche. Cham: Springer International Publishing, pp. 147-58.

Norum, Roger. 2016. Barentsburg and Beyond: Coal, Science, Tourism, and the Geopolitical Imaginaries of Svalbard's "New North". In Postcolonial Perspectives on the European High North. Unscambling the Arctic. Edited by Graham Huggan and Lars Jensen. London: Palgrave Macmillan, pp. 31-65.

Nuttal, Mark. 2010. Narratives of History, Environment and Global Change: Expeditioner-Tourists in Antarctica. In Tourism and Change in Polar Regions. Climate, Environment and Experience. Edited by C. Michael Hall and Jarkko Saarinen. New York: Routledge, pp. 201-14. 
Øseth, Ellen. 2010. Klimaendringer i Norsk Arktis: Konsekvenser for Livet i Nord. Rapportserie 136. Tromsø: Norwegian Polar Institute.

Reeder-Myers, Leslie A. 2015. Cultural Heritage at Risk in the Twenty-First Century: A vulnerability Assessment of Coastal Archeological Sites in the United States. Journal of Island and Coastal Archaeology 19: 436-45. [CrossRef]

Riksrevisjonen. 2007. Riksrevisjonens Undersøkelse av Forvaltningen av Svalbard. Dokument nr. 3:8 (2006-2007). Available online: https:/ / evalueringsportalen.no/evaluering/riksrevisjonens-undersokelseav-forvaltningen-av-svalbard/Dok_3_8_2006_2007.pdf/@@inline (accessed on 21 January 2017).

Risan, Thomas, Annika Haugen, and Johan Mattsson. 2011. Local Cultural Heritage Management under Climate Change in Norway. In Municipalities Addressing Climate Change: A Case Study of Norway. Edited by Ilan Kelman. Bingley: Emerald Group Publishing Limited, pp. 93-111.

Roura, Ricardo. 2010. Cultural Heritage Tourism in Antarctica and Svalbard: Patterns, Impact, and Policies. In Tourism and Change in Polar Regions. Climate, Environment and Experience. Edited by C. Michael Hall and Jarkko Saarinen. New York: Routledge, pp. 180-203.

Roura, Ricardo. 2011. From extraction to exhibition. Tourism at a disused marble quarry at Ny-London, Svalbard. In Polar Settlements-Location, Techniques and Conservation. Edited by Susan Barr and Paul Chaplin. Compiled and Edited for the International Polar Heritage Committee of the International Council on Monuments and Sites. Fjellhamar: ICOMOS IPHC, pp. 14-23.

Sabbioni, Cristina, Peter Brimblecombe, and May Cassar. 2010. The Atlas of Climate Change Impact on European Cultural Heritage. Scientific Analysis and Management Strategies. London: Anthem Press.

Sander, Gunnar, Inger Hanssen-Bauer, Arne Bjørge, and Pål Prestrud. 2006. The Environmental Monitoring of Svalbard and Jan Mayen-MOSJ: Documentation of the System and the First Assessments of the State of the Environment. NPI Report Series No. 123; Tromsø: Norwegian Polar Institute.

Sandodden, Irene Skauen, Hilde Tokle Yri, and Helge Solli. 2013. Kulturminneplan for Svalbard 2013-2023 [Plan for the Management of Cultural Heritage in Svalbard 2013 to 2023]. Longyearbyen: Sysselmannen på Svalbard [Governor of Svalbard].

Sandodden, Irene Skauen. 2013. Katalog Prioriterte Kulturminner og Kulturmiljøer på Svalbard [Catalouge of Prioritized Cultural Heritage in Svalbard]. Available online: http:/ / www.sysselmannen.no/Documents / Sysselmannen_dok/Trykksaker/Katalog_prioriterte_kulturminner_paa_Svalbard_versjon_1_1_2013_ komprimert.pdf (accessed on 15 January 2017).

Statistics Norway. 2016. Dette er Svalbard 2016. Hva Tallene Forteller [This Is Svalbard 2016. What the Figures Say]; Oslo: Statistics Norway.

Steinberg, Philip E., Jeremy Tasch, and Hannes Gerhardt, eds. 2015. Contesting the Arctic. Politics and Imaginaries in the Circumpolar North. London: I.B Tauris and Co. Ltd.

Stewart, Emma J., Diane Draper, and Margaret E. Johnston. 2005. A Review of Tourism Research in the Polar Regions. Arctic 58: 383-94. [CrossRef]

Svalbard Environmental Protection Act. 2001. Act of 15 June 2001 No.79 Relating to the Protection of the Environment in Svalbard. Available online: https://lovdata.no/dokument/NL/lov/2001-06-15-79?q= svalbard (accessed on 15 January 2017).

Svalbard Treaty. 1920. Treaty between Norway, The United States of America, Denmark, France, Italy, Japan, the Netherlands, Great Britain and Ireland and the British Overseas Dominions and Sweden Concerning Spitsbergen. Available online: https:/ / lovdata.no/dokument/NL/lov/1920-02-09 (accessed on 15 January 2017).

Thuestad, Alma Elizabeth, Hans Tømmervik, Stian Solbø, Stine Barlindhaug, Anne Cathrine Flyen, Elin Rose Myrvoll, and Bernt Johansen. 2015a. Monitoring cultural heritage environments in SvalbardSmeerenburg, a whaling station on Amsterdam Island. EARSeL eProceedings 14: 37-50. [CrossRef]

Thuestad, Alma Elizabeth, Hans Tømmervik, and Stian Andre Solbø. 2015b. Assessing the impact of human activity on cultural heritage sites in Svalbard: A remote sensing study of London. The Polar Journal 5: 428-45. [CrossRef]

Timothy, Dallen J. 2010. Contested place and the legitimization of sovereignty claims through tourism in Polar Regions. In Tourism and Change in Polar Regions. Climate, Environment and Experience. Edited by C. Michael Hall and Jarkko Saarinen. New York: Routledge, pp. 288-300. 
Veselov, Alexander. 2015. In 2018 Tourism on Spitsbergen Will Bring More Money than Coal Mining. The Arctic. Available online: http:/ / arctic.ru/analitic/20151015/194659.html (accessed on 17 October 2018).

Viken, Arvid. 2011. Tourism, research, and governance on Svalbard: A symbiotic relationship. Polar Record 47: 335-47. [CrossRef] 